\title{
IN VITRO SENSITIVITY OF DERMATOPHYTES TO UREA
}

\author{
José Eduardo Costa Martins, Simone Miwa Corim, Giovanna Letícia Hernández
} Arriagada, Natalina Takahashi de Melo, and Elisabeth Maria Heins

\footnotetext{
Martins JEC, Corim SM, Arriagada GLH, Melo NT de, Heins EM. In vitro sensitivity of dermatophytes to urea. Clinics. 2006;61(1):9-14.
}

OBJECTIVE: Urea is commonly used as a keratolytic substance in the treatment of onychomycoses to improve the penetration of antifungal drugs in the lesion sites. The aim of the present study was to investigate the inhibitory action of urea on samples of dermatophytes in vitro.

METHOD: Minimum inhibitory concentration of urea was determined for 31 samples of dermatophytes cultured in Sabourauddextrose broth containing different concentrations (7.5\% up to 40\%) of urea. Absence of growth was the criterion adopted to determine the minimum inhibitory concentration.

RESULTS: The majority of samples (87\%) were sensitive to urea at 12.5\%, or less. 2 isolates of Trichophyton tonsurans and 2 of Trichophyton rubrum required $30 \%$, and $40 \%$ urea, respectively, to be completely inhibited.

CONCLUSION: In vitro results demonstrate inhibitory activity of urea on dermatophytes, suggesting that it could be used as an adjuvant in topical treatments.

KEYWORDS: Onychomycoses. Dermatophytoses. Dermatophytes. Urea. Inhibitory Activity.

\section{INTRODUCTION}

Dermatophytes are fungi capable of invading keratinized regions such as skin, hair, and nails of human beings and animals, causing diseases known as dermatophytoses. ${ }^{1}$ Among the species of anthropophilic dermatophytes, Trichophyton rubrum is the most adapted to human beings and is one of the most important agents of tinea unguium, tinea pedis, tinea manuum, tinea corporis, and tinea capitis. ${ }^{2-10}$ Treatment with topical antimycotics are generally not indicated for hyperkeratotic type tinea pedis and onychomycoses. In these cases, griseofulvine and, more re-

Laboratory of Medical Mycology of the Institute of Tropical Medicine (LIM 53), São Paulo University Medical School - São Paulo/SP, Brazil.

Department of Dermatology, São Paulo University Medical School - São Paulo/SP, Brazil.

Email: jecm@usp.br

Received for publication on November $05,2005$.

Accepted for publication on November 18, 2005. cently, itraconazole and terbinafine have been frequently administered. However, such drugs can cause intestinal and hepatic disturbances or interactions with other consumed drugs, precluding oral treatment. ${ }^{11}$

Several agents for topical use are commercially available for the treatment of superficial mycoses. The medication is prescribed according to the etiology of the fungus, site, and extent of the lesions. Clinical aspects of the host are important for establishing the choice of a topical or systemic treatment. ${ }^{12}$

Treatment is usually prolonged for hyperkeratotic lesions of the feet and nails. In order to shorten it, drugs associated with keratolytic agents have been tested. Studies have shown that bifonazole plus urea can be useful in this situation. ${ }^{12-14,16}$ The application of urea along with butenafine can also result in earlier improvement of dermatological symptoms of hyperkeratotic-type tinea pedis ${ }^{15}$ as well as when associated with lanoconazole. ${ }^{11}$

In summary, these studies have shown that the kerato- 
lytic/exfoliative action of urea can reduce the period of treatment of hyperkeratotic lesions. However, there are no reports on the inhibitory activity of urea on dermatophytes, except for the work of Faergemann \& Swanbeck ${ }^{17}$ who investigated the in vitro action of urea against a sample of T. rubrum, demonstrating that the minimal inhibitory concentration (MIC) of a solution containing urea, lactic acid, and propylene glycol was lower in comparison to the same solution without urea.

The aim of this study was to evaluate in vitro the inhibitory activity of urea on dermatophytes samples.

\section{MATERIALS AND METHODS}

\section{Microorganisms}

Thirty-one samples of dermatophytes isolated from patients presenting skin $(n=18)$ and nail lesions $(n=13)$ were analyzed (Table 1).

\section{Sample Identification}

Initially, a direct examination of the samples treated with $\mathrm{KOH} 20 \%$ was performed by optical microscopy. Then, the samples were cultured in tubes containing mycobiotic agar and maintained at $25^{\circ} \mathrm{C}$. The macroscopic aspect of the colonies was observed during a 2-week period.

To identify the isolate at genus and species level, microcultures of the dermatophytes were carried out in potato agar maintained at $25^{\circ} \mathrm{C}$, followed by microscopic examination of the slides stained with lactophenol cotton blue.

\section{Susceptibility to urea}

In order to determine the in vitro sensitivity to urea, all the dermatophytes samples were cultured in $18 \times 180$ $\mathrm{mm}$ tubes with $10 \mathrm{~mL}$ of Sabouraud-dextrose broth having the following concentrations of urea: $7.5 \%, 10 \%$, $12.5 \%, 20 \%, 30 \%$, and $40 \%$. All the cultures were incubated at $30^{\circ} \mathrm{C}$. Tubes containing only Sabouraud-dextrose broth as culture medium were used as positive growth controls.

\section{Minimal inhibitory concentration (MIC) determination}

Absence of growth was the criterion adopted to define the MIC of urea, which was determined between the $7^{\text {th }}$

Table 1 - Dermatophyte identification of 31 clinical samples studied

\begin{tabular}{|c|c|c|c|}
\hline Samples & Reference number & Location & Origin \\
\hline T. rubrum & 11 & Inguinal region & Laboratory of Mycology - IMT \\
\hline T. rubrum & 16 & Foot & Laboratory of Mycology - IMT \\
\hline T. rubrum & 22 & Foot & Dermatology Service-HCFMUSP \\
\hline T. rubrum & 25 & Foot & Dermatology Service - HCFMUSP \\
\hline T. rubrum & 29 & Foot & Proença Laboratory \\
\hline T. rubrum & 56 & Foot & Dermatology Service - HCFMUSP \\
\hline T. rubrum & 68 & Foot & Proença Laboratory \\
\hline T. rubrum & 70 & Foot & Proença Laboratory \\
\hline T. rubrum & 109 & Nail & Laboratory of Mycology - IMT \\
\hline T. rubrum & 114 & Nail & Laboratory of Mycology - IMT \\
\hline T. rubrum & 115 & Nail & Laboratory of Mycology - IMT \\
\hline T. rubrum & 117 & Foot & Laboratory of Mycology - IMT \\
\hline T. rubrum & 118 & Foot & Laboratory of Mycology - IMT \\
\hline T. rubrum & 119 & Foot & Laboratory of Mycology - IMT \\
\hline T. rubrum & 121 & Glutea region & Laboratory of Mycology - IMT \\
\hline T. rubrum & 126 & Nail & Laboratory of Mycology - IMT \\
\hline T. rubrum & 154 & Nail & Proença Laboratory \\
\hline T. rubrum & 155 & Nail & Laboratory of Mycology - IMT \\
\hline T. rubrum & 156 & Nail & Laboratory of Mycology - IMT \\
\hline T. tonsurans & 04 & Scalp & Laboratory of Mycology - IMT \\
\hline T. tonsurans & 06 & Nail & Dermatology Service -HCFMUSP \\
\hline T. tonsurans & 09 & Foot & Laboratory of Mycology - IMT \\
\hline T. tonsurans & 24 & Foot & Dermatology Service -HCFMUSP \\
\hline T. tonsurans & 34 & Nail & Laboratory of Mycology - IMT \\
\hline T. tonsurans & 125 & Nail & Proença Laboratory \\
\hline T. mentagrophytes & 10 & Foot & Laboratory of Mycology - IMT \\
\hline T. mentagrophytes & 33 & Nail & Proença Laboratory \\
\hline T. mentagrophytes & 83 & Nail & Laboratory of Mycology - IMT \\
\hline T. mentagrophytes & 153 & Foot & Laboratory of Mycology - IMT \\
\hline M. canis & 142 & Nail & Proença Laboratory \\
\hline M. gypseum & 110 & Foot & Brigadeiro Hospital \\
\hline
\end{tabular}


and $10^{\text {th }}$ day, when the control tube had well developed typical colonies.

The growth of the samples during the incubation time was recorded and graded as follows: $\mathrm{C}=$ control tube (plentiful growth); $(+)$ = weak growth; $(++)=$ moderate growth; $(+++)$ $=$ plentiful growth; $(-)=$ absence of growth (Figure 1$)$.

\section{RESULTS}

The causative agents in 31 samples of dermatophytes from patients presenting skin and nails lesions were identified as Trichophyton rubrum (19), Trichophyton tonsurans (6), Trichophyton mentagrophytes (4), Microsporum gypseum (1), and Microsporum canis (1) (Table 1).

Of note is the high frequency of T. rubrum in feet and nails in the samples that showed growth inhibition atconcentrations lower or equal to $10 \%$.

Two T. tonsurans isolates were sensitive at $30 \%$ urea, and 2 T. rubrum isolates were sensitive at $40 \%$ (Table 2).

The sample distribution according to the lesion site is presented in Table 3.

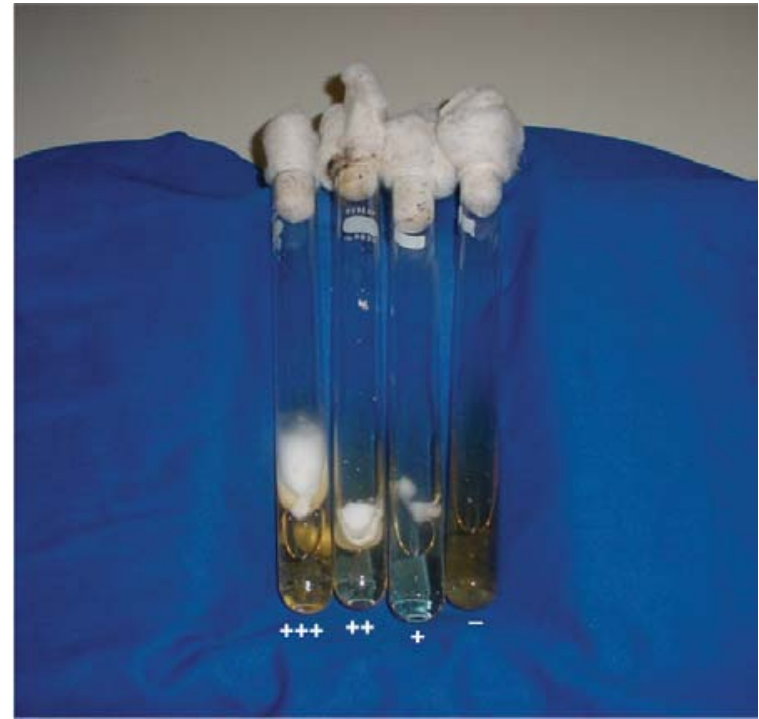

$\begin{array}{ll}(+++)=\text { plentiful growth } & (++)=\text { moderate growth } \\ (+)=\text { weak growth } & (-)=\text { absence of growth }\end{array}$

Figure 1 - Illustration of the classification scheme of growth patterns of dermatophytes during the incubation of the samples in the presence or absence of urea.

Table 2 - Growth index of 31 isolates of dermatophytes sown in Sabouraud-dextrose broth at $30^{\circ} \mathrm{C}$ in the presence of different concentrations of urea

\begin{tabular}{|c|c|c|c|c|c|c|c|}
\hline $\begin{array}{l}\text { Urea } \\
\text { Samples }\end{array}$ & $\mathrm{C}^{*}$ & $7.5 \%$ & $10 \%$ & $\begin{array}{l}12.5 \% \\
\text { entratior }\end{array}$ & $20 \%$ & $30 \%$ & $40 \%$ \\
\hline T. rubrum (11) & $+++* *$ & +++ & +++ & - & - & - & - \\
\hline T. rubrum (16) & +++ & - & - & - & - & - & - \\
\hline T. rubrum (22) & +++ & + & + & - & - & - & - \\
\hline T. rubrum (25) & +++ & + & + & - & - & - & - \\
\hline T. rubrum (29) & +++ & - & - & - & - & - & - \\
\hline T. rubrum (56) & ++ & - & - & - & - & - & - \\
\hline T. rubrum (68) & +++ & +++ & +++ & - & - & - & - \\
\hline T. rubrum (70) & +++ & ++ & - & - & - & - & - \\
\hline T. rubrum (109) & +++ & - & - & - & - & - & - \\
\hline T. rubrum (114) & +++ & +++ & +++ & ++ & ++ & + & - \\
\hline T. rubrum (115) & +++ & +++ & +++ & ++ & ++ & ++ & - \\
\hline T. rubrum (117) & +++ & +++ & +++ & - & - & - & - \\
\hline T. rubrum (118) & +++ & +++ & +++ & - & - & - & - \\
\hline T. rubrum (119) & +++ & +++ & +++ & - & - & - & - \\
\hline T. rubrum (121) & +++ & +++ & +++ & - & - & - & - \\
\hline T. rubrum (126) & +++ & ++ & ++ & - & - & - & - \\
\hline T. rubrum (154) & +++ & - & - & - & - & - & - \\
\hline T. rubrum (155) & +++ & + & - & - & - & - & - \\
\hline T. rubrum (156) & +++ & + & + & - & - & - & - \\
\hline T. tonsurans (04) & +++ & + & + & - & - & - & - \\
\hline T. tonsurans (06) & +++ & ++ & - & - & - & - & - \\
\hline T. tonsurans (09) & +++ & +++ & ++ & ++ & ++ & - & - \\
\hline T. tonsurans (24) & +++ & ++ & - & - & - & - & - \\
\hline T. tonsurans (34) & +++ & +++ & +++ & - & - & - & - \\
\hline T. tonsurans (125) & +++ & +++ & +++ & ++ & ++ & - & - \\
\hline T. mentagrophyte(10) & +++ & +++ & +++ & - & - & - & - \\
\hline T. mentagrophyte (33) & +++ & ++ & + & - & - & - & - \\
\hline T.mentagrophytes $(83)$ & +++ & ++ & - & - & - & - & - \\
\hline T. mentagrophytes (153) & +++ & + & - & - & - & - & - \\
\hline M. gypseum (110) & +++ & - & - & - & - & - & - \\
\hline M. gypseum (161) & +++ & ++ & - & - & - & - & - \\
\hline M. canis (142) & ++ & - & - & - & - & - & - \\
\hline
\end{tabular}

*C = control tube (plentiful growth); ** Growth index: + weak growth; ++ moderate growth; +++ plentiful growth; - absence of growth 
Table 3 - Distribution of dermatophytes isolates by lesion site

\begin{tabular}{|c|c|c|c|c|c|c|}
\hline \multirow[t]{2}{*}{ Lesion Sites } & \multicolumn{5}{|c|}{ Dermatophytes } & \multirow[t]{2}{*}{ Total } \\
\hline & T. tonsurans & T. rubrum & T. mentagrophytes & M. canis & M. gypseum & \\
\hline Nail & 03 & 07 & 02 & - & - & 13 \\
\hline Scalp & 01 & - & - & - & - & 01 \\
\hline Glútea region & - & 01 & - & - & - & 01 \\
\hline Foot & 02 & 10 & 02 & - & 01 & 15 \\
\hline Inguinal region & - & 01 & - & - & - & 01 \\
\hline Total & 06 & 19 & 04 & 01 & 02 & 31 \\
\hline
\end{tabular}

\section{DISCUSSION}

Most dermatologists use topical formulations of antifungal drugs. The choice of treatment depends on the etiology, location, clinical form, and extent of the fungal lesions. In many cases, the patient's underlying conditions determine the treatment choice: creams, solutions, powders, gels, or capsules. ${ }^{12}$

The therapeutic schemes for hyperkeratotic type tinea pedis and onychomycosis, mainly for the toenails, are seriously problematic, because the results with griseofulvine are not sufficiently satisfactory and side effects are frequent. More recently, itraconazole and terbinafine have been used. These antifungal agents produce fewer side effects, but their high cost can make the treatment impractical.

Additionally, topical antifungal drugs are also unsatisfactory due to the poor penetration into the nails. However, earlier studies have shown that the use of propyleneglycol associated with urea and lactic acid produces effective results for the treatment of the nail tissue. Among 23 patients presenting onychomycosis caused by Candida albicans and Trichophyton rubrum, 21 had good in vivo responses with only topical treatment using this combination. ${ }^{17}$

The association of topical antifungal drugs with urea has been shown to improve treatment outcomes. Association of bifonazole with $10 \%$ urea to treat patients with tinea pedis produced clinical improvement in $92 \%$ of the cases after 12 weeks. Additionally, the treatment of the hyperkeratotic-type tinea pedis with topic butenafine hydrochloride plus $20 \%$ urea provided an earlier dermatological improvement compared to the use of oral antifungal drugs. ${ }^{15}$

Regarding etiologies among the dermatophytoses, $T$. rubrum has been shown to have a high incidence as a causative agent. ${ }^{16,18,20}$ In our study, the most frequently isolated dermatophyte from different body regions was T. rubrum.

An earlier study evidenced the antimycotic activity of urea at 5\% against a $T$ rubrum isolate in vitro. ${ }^{17}$ Our data show that the majority of samples, including T. rubrum, were sensitive to $12.5 \%$ urea. Of note is that only 4 isolates, 2 of $T$. tonsurans and 2 of T. rubrum, respectively, required $30 \%$ or $40 \%$ urea for their complete inhibition. These data are related to clinical observations, because lesions caused by T. rubrum are sometimes difficult to treat, and recurrence frequently occurs. ${ }^{21}$

These in vitro results demonstrate the inhibitory activity of urea on dermatophytes, suggesting that this keratolytic agent may also have a fungicide action and that it could be used as an adjuvant in topical treatment. Further studies correlating time of treatment and cure percentage of patients using topical medications in the presence of urea must be conducted for a better evaluation of its antimycotic action.

\section{RESUMO}

Martins JEC, Corim SM, Arriagada GLH, Melo NT de, Heins EM. Sensibilidade in vitro de dermatófitos à uréia. Clinics. 2006;61(1):9-14.

OBJETIVO: A uréia é comumente usada como substância queratolítica no tratamento das onicomicoses no intuito de melhorar a penetração das drogas antifúngicas. O objetivo deste estudo foi investigar a ação inibitória in vitro da uréia em amostras de dermatófitos

MÉTODOS: A concentração inibitória mínima da uréia foi determinada para trinta e uma amostras de dermatófitos semeadas em meio de cultura Sabouraud-dextrose contendo diferentes concentrações (7,5\% até 40\%) de uréia. Ausência de crescimento foi o critério adotado para a determinação 
da concentração inibitória mínima.

RESULTADOS: A maioria das amostras (87\%) foi sensível à uréia em concentrações de 12,5\% ou menos. Apenas dois isolados de Trichophyton tonsurans e dois de Trichophyton rubrum foram inibidos completamente na presença de $30 \%$ e $40 \%$ de uréia, respectivamente.
CONCLUSÃO: Os resultados in vitro demonstraram atividade inibitória da uréia sobre os dermatófitos, sugerindo que possa ser usada como um adjuvante em tratamentos tópicos.

UNITERMOS: Onicomicoses. Dermatomicoses. Dermatófitos. Uréia. Ação Inibitória.

\section{REFERENCES}

1. Lacaz C da S, Porto E, Martins JEC, Heins-Vaccari EM, Melo NT. Tratado de Micologia Médica Lacaz. São Paulo, Sarvier 2002.

2. Zaias N. Onychomycosis. Arch Dermatol. 1972;195:263-74.

3. Charif MA, Elewski BE. Historical perspectives on onychomycosis. Dermatol Ther. 1997;3:43-5.

4. Rippon JW. The changing epidemiology and emerging patterns of dermatophytes species. Curr Trop Med Mycol. 1985;1:209-34.

5. Coloe SV, Baird RW. Dermatophyte infections in Melbourne, trends from 1961-1964 to 1995-1996. Pathology. 1999;31:395-7.

6. Schwinn A, Ebert J, Brocker EB. Frequency of Trichophyton rubrum in tinea capitis. Mycoses. 1995;38:1-7.
7. Weitzman I, Summerbell RC. The dermatophytes. Clin Microbiol Rev. 1995;8:240-59.

8. Anstey A, Lucke TW, Philpot C. Tinea capitis caused by Trichophyton rubrum. Br J Dermatol. 1996;135:113-5.

9. Kenna ME, Elewski BE. A U.S. epidemiologic survey of superficial fungal diseases. J Am Acad Dermatol. 1996;35:539-42.

10. Elewski BE. Onychomycosis: pathogenesis, diagnosis, and management. Clin Microbiol Rev. 1998;11:415-29.

11. Tanuma H; Tanuma M; Abe M, Kume H. Usefulness of lanoconazole (Astat) cream in the treatment of hyperkeratotic type tinea pedis. Comparative study of monotherapy and combination therapy with $10 \%$ urea ointment (Pastaron). Mycoses. 2001;44:181-90. 
12. Torres-Rodriguez JM. New topical antifungal drugs. Arch Med Res. $1993 ; 24: 371-5$

13. Lackner TE; Clissold SP. Bifonazole. A review of its antimicrobial activity and therapeutic use in superficial mycoses. Drugs. 1989;38:204-25.

14. Reisberger EM, Szeimies RM. Therapy of onychomycosis. Med Klin. 2000;95:618-28.

15. Tanuma H, Doi M, Ohta Y, Abe M, Kume H, Mukai H, et al. Butenafine hydrochloride (Mentax) cream for the treatment of hyperkeratotic type tinea pedis and its transfer into the horny layer, with or without concomitant application of $20 \%$ urea ointment (keratinamin). Mycoses. 2001;44:287-99.

16. Tanuma H, Doi M, Sato N, Nishiyama S; Abe M; Kume H, et al. Bifonazole (Mycospor cream) in the treatment of moccasin-type tinea pedis. Comparison between combination therapy of bifonazole cream $+10 \%$ urea ointment (Urepearl) and occlusive dressing therapy with same agents. Mycoses. 2000;43:129-37.
17. Faergemann J, Swanbeck G. Treatment of onychomycosis with a propylene glycol-urea-lactic acid solution. Mycoses. 1989;32:536-40.

18. Chinelli PAV, Sofiatti AA, Nunes RS, Martins JEC. Dermatophyte agents in the city of São Paulo, from 1992 to 2002. Rev Inst Med trop Sao Paulo. 2003;45:259-63.

19. Mezzari A. Frequency of dermatophytes in the metropolitan area of Porto Alegre, RS, Brazil. Rev Inst Med trop Sao Paulo. 1998;40:71-6.

20. Gambale W, Paula CR, Corrêa, B, Purchio A. Incidência de micoses superficiais em São Paulo, Capital. An Bras Dermatol. 1987;62:193-4.

21. Sampaio SAP, Castro RM, Rivitti EA. Dermatologia Básica. São Paulo Sarvier, 1983. p 337. 